ARTICLE

https://doi.org/10.1057/s41599-019-0372-0

\title{
What's in a name? Measuring access to social activities with a field experiment
}

\author{
Cornel Nesseler ${ }^{1 \star}$, Carlos Gomez-Gonzalez (D) $^{2} \&$ Helmut Dietl ${ }^{2}$
}

\begin{abstract}
Today's societies increasingly consist of members who migrated from other countries and regions, and their functioning depends heavily on integrating their diverse members. Interactions with the local population through social activities enhance integration. Despite its relevance, however, previous research has largely overlooked the role of the local population in social integration. This paper introduces an objective method for analyzing access to social activities. Switzerland includes diverse native groups, who differ in culture and language, and a high percentage of foreigners. Applications were sent by email to amateur Swiss football clubs, asking if it is possible to join a training session. The applications differed only in the contact name. Individuals with foreign names, as well as individuals with Swiss names from some other native groups, received significantly fewer responses. The findings are relevant for governing institutions and policy-makers. Researchers who study social integration may find the novel method used here of considerable interest.
\end{abstract}

\footnotetext{
${ }^{1}$ Norwegian University of Science and Technology, Trondheim, Norway. ${ }^{2}$ University of Zurich, Zürich, Switzerland. *email: cornel.m.nesseler@ntnu.no
} 


\section{Introduction}

ocial integration-the extent to which individuals interact with other members of a group (Katz and Kahn, 1978) - is a necessity for all societies (Portes, 1997; Rumbaut, 1997). Research demonstrates that social integration helps prevent mental and physical illness (Berkman et al., 2000), increases wellbeing (Putnam, 2001), and improves group performance (Smith et al., 1994). The very survival of societies and countries that fail to integrate their citizens is at stake (Hutchinson, 2000; May, 2013). As a result, integration research is one of the most prominent subfields of the social sciences (De Haas, 2005; Massey, 1988; Nowotny et al., 2009).

Integration research depends on objective measures (Snauwaert et al., 2003; Van Oudenhoven and Eisses, 1998). However, like other social concepts, such as trust (Glaeser et al., 2000), social integration is not easily quantified. The literature relies on approximations that reflect the level of integration of foreign groups through participation in social and other activities (Laurentsyeva and Venturini, 2017). To date, research does not provide a measure of social integration that captures the actions of the local population (Arends-Tóth and Van de Vijver, 2007; Demes and Geeraert, 2014). This paper attempts to fill that gap by introducing a new method to analyze access to social activities.

Field experiments have been widely used to analyze access to the labor market, the sharing economy, and other social domains. In these studies, researchers construct profiles of people applying for a job (Bertrand and Mullainathan, 2004; Kroft et al., 2013; Pager et al., 2009), renting an apartment (Edelman et al., 2017), requesting a ride (Ge et al., 2016), or asking for help participating in elections (Butler and Broockman, 2011). This method isolates the effect of a given attribute (e.g., race or gender) as reflected in the name of the applicant. We used this approach to analyze whether individuals have equal opportunity to participate in social activities in Switzerland.

We created email accounts with typical French-speaking Swiss, German-speaking Swiss, Italian-speaking Swiss, and foreign names. Using these accounts, we contacted amateur football clubs asking for the opportunity to participate in a training session. We analyzed the influence of the name on the response. Switzerland is an ideal country for such an experiment because it consists of distinct subgroups characterized not only by substantial regional and cultural differences, but also by different official languages (Erk, 2007). Compared to previous work on social integration, this approach has four main advantages.

First, the actions of the host society are studied. Traditional measures tend to focus on characteristics of immigrants, such as the extent to which they read local newspapers, speak the language, or plan to stay in the country (Avitabile et al., 2013; Hainmueller et al., 2017). Although such measures indicate how well immigrants have adapted to their new society, they fail to indicate how well their new society has accepted them. Our measure shows how the host population treats individuals by allowing or denying access to social activities.

Second, the field experiment is an objective measure. Previous research using data from surveys often has the limitation that variables are self-reported. This is perhaps not a problem for objective variables such as age, gender, and marital status, but for many other variables, which are at least partly subjective, selfreporting may result in distortions due to social desirability (Hofmann et al., 2015) and other biases. The measure used here relies on observed behavior, and therefore avoids problems associated with self-reporting.

Third, the method ensures that the results are not distorted by factors such as appearance, attitude, or accent. Such "hidden" nonconscious factors often influence administrative or survey studies and potentially bias the results (Bertrand and Mullainathan, 2004). Any such influence is avoided here, because the experimental manipulation is limited to a name.

Fourth, we used a social activity relevant for Swiss and nonSwiss alike. Amateur team sports cover all aspects of social interaction (Allen, 2003; Carron and Spink, 1993; Duarte et al., 2012; Eccles and Tenenbaum, 2007) and have a positive influence on integration (Lowe, 2018; Walseth, 2008). Therefore, this seems to be an ideal setting to measure access to social activities. In addition, the rules of football equally apply to all participants. As a result, prejudices based on racial, religious, or linguistic differences should have little importance. Compared to professional team sports, where economics overshadows everything else, amateur sports have the advantage that they are not dominated by economic interests. Since football is by far the most popular sport in Switzerland (Schweizerische Eidgenossenschaft, 2019a), we selected amateur football as the setting for the experiment.

\section{Results}

Experiment set-up. We identified 1188 football clubs in Switzerland, all of which have at least one amateur team (some have more than one). We included only amateur clubs that compete in leagues with no foreign player restrictions, namely, League 2 $(n=114)$, League $3(n=272)$, League $4(n=439)$, and League 5 $(n=363){ }^{1}$ For each club, we identified the email address of the coach. In cases where a club had more than one team, we randomly selected one and identified the email of its coach.

Figure 1 shows the geographic location of football clubs in Switzerland. Color indicates the primary language used in each club.

Switzerland has a population of about 8.5 million, 25 percent of whom are foreign-born. No other country in Europe with more than 1 million inhabitants has a higher percentage. Geographically, linguistically, and culturally, Switzerland can be divided into four regions: German in the north and northeast, French in the west, Italian in the south, and Romansh in the southeastern trilingual canton of Grisons. According to the Swiss Federal Statistical Office, 62.8 percent of the population speaks primarily German, 22.9 percent French, 8.2 percent Italian, and 0.5 percent Romansh (Schweizerische Eidgenossenschaft, 2019b). The rest are foreigners who do not primarily speak one of the four official languages.

To measure the access to social activities, we sent one email to each of the 1188 coaches, asking to participate in a training session. Only one email was sent to each club, as multiple emails could have aroused suspicion. Responses were categorized as (1) no response or rejection, ${ }^{2}$ (2) positive response, (3) positive response with additional inquiry. In the third group, a positive response preceded further inquiries (e.g., "What position do you play?"; "Where did you play before?"). To examine the response rate, we created a binary variable that takes value zero for no responses and rejections, and value one for positive responses and positive responses with additional inquiries.

The email shows only an interest in joining a trial training session and avoids references to further attributes. The language of the email coincides with the language of the homepage of the club. ${ }^{3,4} \mathrm{We}$ did not send any emails in Romansh because very few amateur clubs use Romansh. Thus, an empirical examination would not have had enough observations for this group.

The ethics board of the University of Zurich permitted us to send the following email: 


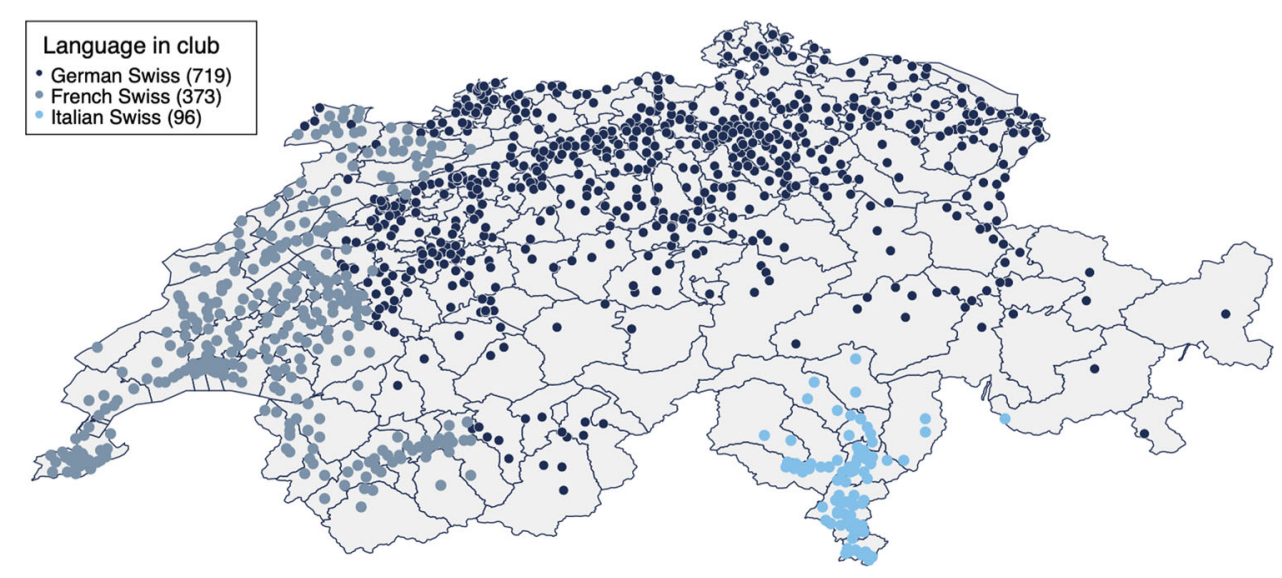

Fig. 1 Amateur football clubs and their primary language in Switzerland.

Subject: Trial practice

Hello,

I would like to take part in a trial training session with your team. I have already played at a similar level. Could I come for a trial training session?

Many thanks

Name

The names were generated as follows. First, we asked the Linguistics Department of the University of Zurich to identify a list of full names (family and given name) that are typical, because of their frequency, for German-speaking Swiss, Frenchspeaking Swiss, Italian-speaking Swiss, and individuals with foreign names, respectively. Table 4 (in the appendix) gives an overview of the names used. Typical names were Daniel Wyss and Christian Meyer (German-speaking Swiss), Nicolas Dubois and Michel Favre (French-speaking Swiss), Marco Bernasconi and Andrea Rezzonico (Italian-speaking Swiss), and Dejan Krasniqi and Bojan Lukic (foreign). ${ }^{5}$ Experiments in labor economics often use a similar approach (Bertrand and Mullainathan, 2004; Edelman et al., 2017; Ge et al., 2016; Kroft et al., 2013; Pager et al., 2009).

The study uses foreign-sounding names that represent a significant percentage of the foreign population in Switzerland. However, the names had to be clearly associated with foreigners and not with a language group in Switzerland. The resulting foreign names can be categorized into three groups: Eastern European, Turkish, and Arabic. Any comparison of the response rate between these groups of foreign names must be made cautiously due to the absence of variation among foreign names (the analysis only includes one Turkish-sounding name).

Response rate. Overall, the response rate to Swiss names was higher than the response rate to foreign names ( 0.619 vs. 0.549 ; average treatment effect (ATE) 0.070; Mann-Whitney $U, z=$ $-2.16, P=0.03, n=1188$ ). Figure 2 shows the number of responses to Swiss and foreign names for French-speaking clubs (0.597 vs. 0.511 ; ATE 0.086; Mann-Whitney $U, z=1.44, P=0.15$, $n=373$ ), German-speaking clubs (0.653 vs. 0.565 ; ATE 0.088 ; Mann-Whitney $U, z=-2.18, P=0.03, n=719)$, and Italianspeaking clubs ( 0.451 vs. 0.560 ; ATE -0.109 ; Mann-Whitney $U$, $z=-0.94, P=0.35, n=96)$.
The results show that foreign names received fewer responses in the French and German parts of Switzerland. In the Italian part, foreign names received more responses. Any interpretation of the results in the Italian part needs to be cautious due to the low number of observations (96). In the next step, we further analyzed the response rate in the different language regions of Switzerland.

Table 1 reports the results of an ordinary least squares estimation with robust standard errors, where the dependent variable takes the value one in case of a response and zero otherwise. ${ }^{6,7}$ We compared the responses for individuals with foreign names and individuals with names from the three largest language groups in Switzerland. Column 1 of Table 1 shows that individuals with foreign names receive significantly fewer responses $(P=0.037)$.

Columns 2, 3, and 4 of Table 1 identify regional differences with respect to group discrimination in Switzerland. Column 2 reports the regression results for German-speaking Swiss clubs. The findings show significant discrimination against French-speaking Swiss $(P=0.063)$ and individuals with foreign names $(P=0.036)$. Italian-speaking Swiss do not suffer from similar discrimination.

As reported in column 3 of Table 1, French-speaking Swiss do not significantly discriminate against any of the other groups, either Swiss or individuals with foreign names. However, even though the result regarding individuals with foreign names is not statistically significant, it is noteworthy that the magnitude $(P=0.243)$ is similar to column 2 and 1 . Column 4 reports a similar result for Italian-speaking clubs: no significant discrimination against individuals with foreign names or any of the other Swiss groups. Again, the findings for Italian-speaking Swiss clubs are difficult to interpret because of the small number of observations and should be considered cautiously. ${ }^{8}$

Moderator factors. Additional factors may influence the type of response. Previous research suggests that politically conservative citizens-those who support right-wing ideologies-may have a negative influence on the integration of foreign groups (Bale, 2008; Helbling et al., 2010; Semyonov et al., 2006). In addition, conflict theory provides a solid ground for research to explore the relationship between ethnic diversity, e.g., percentage of foreigners, and social outcomes (Putnam, 2007). This research argues that the local population considers an increasing number of foreigners as a threat (to both economic status and culture), which leads to distrust. Although this relationship has received extensive empirical support (McLaren, 2003; Putnam, 2007; Schneider, 2008; Semyonov et al., 2004), some settings yield different results (Auer et al., 2019; Hooghe et al., 2009). By relying 

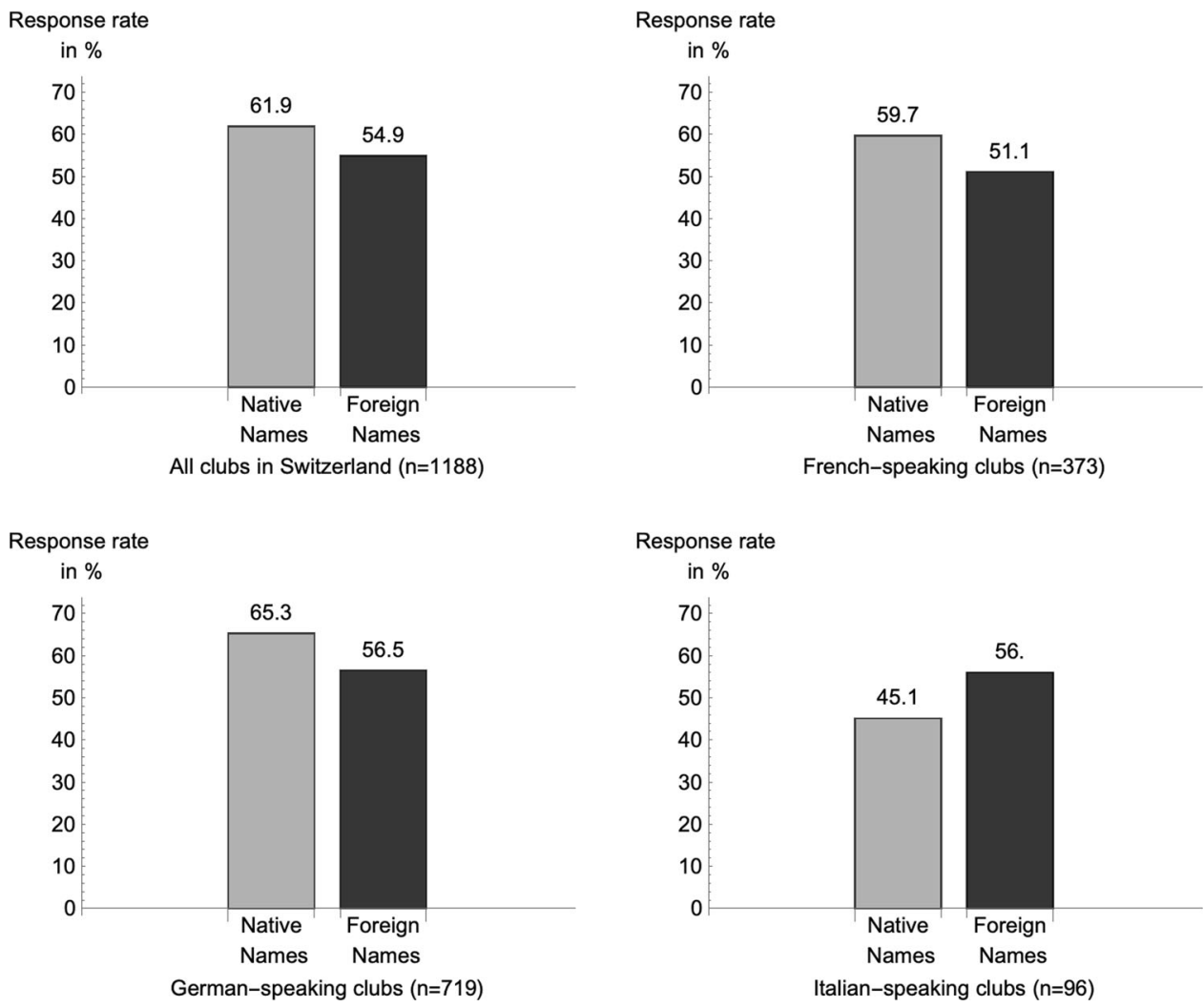

Fig. 2 Response rates for native and foreign names in Switzerland.

Table 1 Results for each part.

Dependent variable: response $(Y e s=1$, No $=0)$

1 All clubs

German-speaking Swiss names omitted French-speaking Swiss names Italian-speaking Swiss names Foreign names

Constant

Observations

$R^{2}$

Standard errors in parentheses

${ }^{\star} p<0.10,{ }^{\star \star} p<<0.05,{ }^{* \star *} p<0.01$ on conflict theory, we expect that the probability of a positive response decreases as the proportion of foreigners living in the area close to a club increases.

We also included the number of inhabitants living in the respective areas because of potential differences between rural and urban areas (Musterd and Ostendorf, 2013). Because club organization, team quality, scouting, and recruiting might still differ across leagues, we included a control in the analysis. In addition, clubs with youth teams could have a lower likelihood of inviting outside players for trials; we therefore included whether or not a club has a youth section. Finally, to control for competition between clubs, we controlled for the number of clubs that play in the same area.

Accordingly, we conducted another analysis, this time with the following moderator variables: share of right-wing votes in the last parliamentary election $(M=0.295, S D=0.101, n=1188)$, proportion of foreigners $(M=0.233, S D=0.116, n=1188)$, number of inhabitants $(M=7433, S D=8593, n=1188)$, other clubs in the area $(M=4.520, S D=4.120, n=1188)$, and presence of a youth section $(M=0.810, S D=0.393, n=1188) .{ }^{10}$ As the Swiss cantons started holidays at different points in time, the response rate might be distorted; we therefore include dummy variables to control for each canton.

The results are reported in Table 2. Column 1 shows that including the control variables did not change the significance level for discrimination against individuals with foreign names $(P=0.048)$. After the inclusion of control variables, the level of discrimination against French-speaking Swiss is no longer statistically significant. As expected, the foreigner rate had a negative influence on response $(P=0.067)$. Column 2 shows that the results for German-speaking clubs did not change substantially with the inclusion of the additional control variables. There 
Table 2 Results with additional control variables.

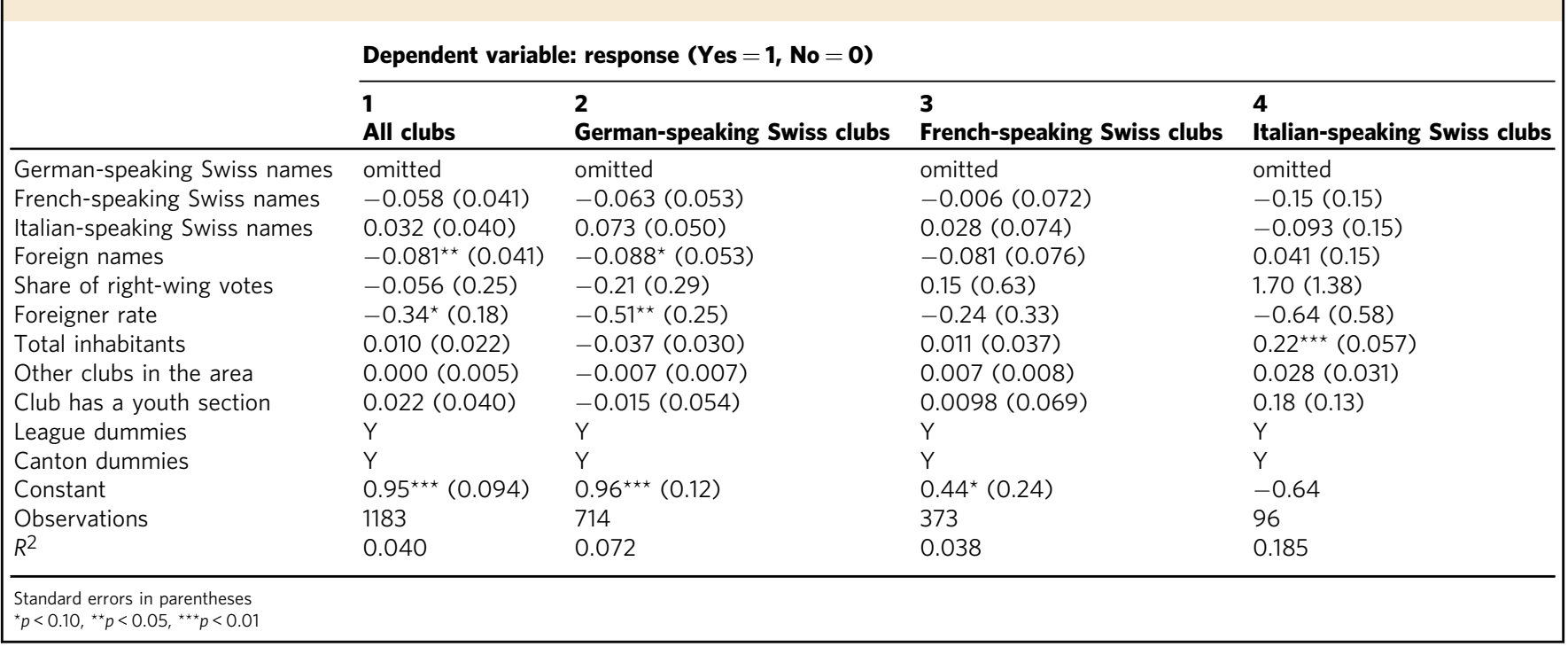

Table 3 Differences among foreign names.

\begin{tabular}{lll} 
& $\begin{array}{l}\text { Dependent variable: response (Yes }=1, \\
\text { No }=\mathbf{0})\end{array}$ \\
\cline { 2 - 3 } & $\begin{array}{l}\mathbf{1} \\
\text { Without control } \\
\text { variables }\end{array}$ & $\begin{array}{l}\text { 2 } \\
\text { With control } \\
\text { variables }\end{array}$ \\
\hline Eastern European & $-0.025(0.048)$ & $-0.024(0.049)$ \\
Turkish & $0.048(0.062)$ & $0.052(0.063)$ \\
Arabian & $-0.18^{\star \star \star}(0.048)$ & $-0.18^{\star \star \star}(0.048)$ \\
Share of right-wing votes & & $-0.14(0.25)$ \\
Foreigner rate & & $-0.35^{\star}(0.18)$ \\
Total inhabitants & & $0.011(0.022)$ \\
Other clubs in the area & & $0.00054(0.0048)$ \\
Club has a youth section & & $0.023(0.040)$ \\
League dummies & & $Y$ \\
Canton dummies & & $Y$ \\
Constant & $0.62^{\star \star \star \star}(0.016)$ & $1.05^{\star \star \star}(0.073)$ \\
Observations & 1183 & 1183 \\
$R^{2}$ & 0.013 & 0.045 \\
\hline Standard errors in parentheses & & \\
${ }^{*} p<0.10,{ }^{\star \star} p<0.05,{ }^{\star \star \star} p<0.01$ & & \\
\hline
\end{tabular}

still is significant evidence for discrimination against individuals with foreign names $(P=0.097)$, but no longer against Frenchspeaking Swiss.

As shown in columns 3 and 4 , the inclusion of additional control variables had no significant effect on the results for French-speaking and Italian-speaking clubs. Moreover, the foreigner rate had a statistically significant effect only for French-speaking clubs. The share of right-wing votes, the number of other clubs in the area, and whether a club has a youth section had no statistically significant influence for any group.

Name origin. Discrimination might not affect all individuals with foreign names equally. Table 3 shows the response rates for the foreign name groups implicit in our analysis-Eastern European, Turkish, and Arabian. Column 1 reports the results without control variables. Individual with Arabian names received significantly fewer positive responses than the other two groups
$(P=0.00)$. Individuals with Turkish and Eastern European names received an equal number of responses. Column 2 shows that this result did not change after the inclusion of control variables.

\section{Discussion}

This paper used a field experiment to measure access to social activities for individuals with foreign names and native names from different regions in Switzerland. The results show that not everyone has the same opportunity to access social activities. For a considerable part of the population, the creation of social networks through social activities is therefore blocked and thus harmful for their successful integration (Granovetter, 1973).

It is reasonable to assume that many individuals with foreign names do not have the same language skills as natives. Thus, social discrimination is likely to be even more pronounced for foreigners without perfect knowledge of the local language (Mattern and Shaw, 2010; Neiman, 2017). However, secondgeneration or third-generation migrants are fluent in the regional language, but still have foreign-sounding names. The present results show that even though they formulate their requests, as well as individuals with native names, these groups face barriers to joining an amateur club.

Apart from traditional prejudices against minority groups and anti-foreign attitudes (McLaren, 2003), psychological research identifies different mechanisms that could explain the discrimination against people with foreign names. Lack of experience in intergroup relationships, uncertainty, and concerns about desirable social outcomes and acceptance often results in anxiety (Pettigrew and Tropp, 2006; Plant and Devine, 2003) or tiredness (Richeson and Trawalter, 2005). The effort that establishing an intergroup relationship requires (in terms of language or cultural aspects, for instance), might render recipients more likely to avoid contact with outgroup individuals.

The results from this experiment show that even cultural differences within the same country determine the access to social activities. French-speaking Swiss names are less likely to receive a response in the German-speaking part of Switzerland. While research mostly focuses on immigrants entering from other countries, it often fails to recognize that different language or cultural groups may also suffer discrimination. Thus, migration of 
the native population should be evaluated not only with respect to its economic impact but also regarding possibilities for successful integration (Borjas, 2006).

The results in Table 3 demonstrate that access to social activities is also unevenly distributed among foreign-sounding names. Singling out specific foreign groups by denying them access to social activities is harmful as it leads to a more segregated society - a process that has negative consequences for all parties involved (Cousins, 1998; Musterd, 2005). Research demonstrates that social contact and interaction reduces prejudices and improves integration (McLaren, 2003; Schneider, 2008). However, this result needs to be considered very cautiously due to the small sample size and the absence of variation in foreign names. Moreover, this analysis is unable to identify other dimensions that might hide behind a name, e.g., socioeconomic status (Gaddis, 2017), and influence the response rate.

In addition, there was a tendency for an increased proportion of foreigners in a neighborhood to decrease the probability that individuals had access to social activities. This result is in line with previous conflict theory research, which suggests that greater ethnic diversity can cause distrust, at least in the short run. (McLaren, 2003; Putnam, 2007; Semyonov et al., 2004; Semyonov et al., 2006). ${ }^{11}$ The implications of this result are relevant as foreigners tend to live in the same areas or neighborhoods, and thus have a more restrictive access to social activities.

Future studies can replicate the study in Switzerland to provide a long-term perspective of barriers to social integration and further explore the mechanisms. Moreover, several organizations actively promote cultural exchange and integration through sport. For example, the European Union officially recognizes the potential of sport in contributing to social inclusion, and encourages direct action (Council of European Union, 2010). The design of the field experiment could be a model for future work to examine barriers to access social activities in different countries. Amateur football is a very popular activity in most countries, and many regions have multiple clubs that compete at amateur level. Therefore, an extensive comparison is possible. Finally, the method can help to examine relevant policy questions by identifying if specific language or cultural groups suffer from discrimination (e.g., Syrians in Germany).

Detailed methods. Using block randomization, we selected one name for each club such that each name was used equally often in each language area (Gerber and Green, 2008). A random number generator was used to construct a 7-digit gmail.com account for each name so that the coach could see the sender's full name not only in the signature but also in the account from which the email was sent. All emails were sent between 10 a.m. and noon on July 3,2018 . We chose this date because it was just before the start of the preparation period for the 2018/19 season, and coaches are usually reluctant to add new players during the regular season, which ran from August 2018 until May 2019.

Responses from coaches were answered as soon as possible; the player informed the coach that he (the player) was now no longer interested in joining the team and thanked the coach for his response.

Although almost all coaches who responded to the emails did so within one week, we counted all responses that were sent until September 1, 2018. The total number of responses to the 1188 email inquiries is 754 .

\section{Data availability}

The data supporting the findings of this study are available at https://doi.org/10.7910/DVN/PZLYUN. Due to the conditions of the ethical committee of the University of Zurich, we deleted all information that identifies individual responses. Emails in the original language (French, German, and Italian) and a full list of names used are given in the Appendix.

Received: 27 July 2019; Accepted: 26 November 2019; Published online: 17 December 2019

\section{Notes}

1 The sample does not include other amateur leagues that have foreign player restrictions (viz., Super League, Challenge League, Promotion League, League 1, and League 2 interregional).

2 We received 25 rejections (18 for Swiss-sounding names) and 434 nonresponses.

3 We chose to use the language of the homepage of the club as some clubs do not use the dominant language of their location.

4 The French, German, and Italian versions of the emails are reported in the Appendix. 5 The full list of names is in the Appendix. All names were chosen based on their frequency in Switzerland. However, because of their phonetic similarity with German, Italian, and French names, we cannot exclude the possibility that email recipients might have misinterpreted the Swiss-sounding names. We perform 166 surveys in public areas in the Swiss-French speaking part $(n=55)$, Swiss-German speaking part $(n=59)$, and Swiss-Italian speaking part $(n=52)$ to confirm the validity of the names. The majority of respondents correctly categorizes the names into Swiss and foreign names, and then into French-speaking Swiss, German-speaking Swiss, and Italian-speaking Swiss. Table 5 in the Appendix shows the complete results and Figures 3 and 4 provide the blank survey sheets.

6 Probit and logit estimations lead to the same results.

7 We find no statistical differences between positive responses and positive responses with additional inquiries for foreign or native names that would alter the results in Table 1. For more details, see Table 6 in the Appendix.

8 Out of the 96 observations in the Swiss-Italian part, 21 observations had a SwissFrench sounding name (9 responses), 24 observations had a Swiss-German sounding name (12 responses), 26 had a Swiss-Italian sounding name (11 responses), and 25 had a Foreign-sounding name (14 responses).

9 We defined the same area as sharing the same first three (out of four) digits in the postal code.

10 We divided the number of inhabitants by 10,000 in the regression analysis to make the results easier to read.

11 A higher foreign share in the area could also increase the probability of coaches and players of having a foreign background themselves, who in any case would need to be well integrated.

\section{References}

Allen JB (2003) Social motivation in youth sport. J Sport Exerc Psy 25(4):551-567 Arends-Tóth J, Van de Vijver F, Jr (2007) Acculturation attitudes: A comparison of measurement methods. J Appl Soc Psychol 37(7):1462-1488

Auer D, Lacroix J, Ruedin D, Zschirnt E (2019) Ethnische Diskriminierung auf dem Schweizer Wohnungsmarkt. BWO https://www.bwo.admin.ch/bwo/de/ home/Wohnungsmarkt/studien-und-publikationen/diskriminierung-auf-derschweizer-wohnungsmarkt.html. Accessed 8 Nov 2019

Avitabile C, Clots-Figueras I, Masella P (2013) The effect of birthright citizenship on parental integration outcomes. J Law Econ 56(3):777-810

Bale $\mathrm{T}$ (2008) Turning round the telescope. Centre-right parties and immigration and integration policy in Europe. J Eur Public Policy 15(3):315-330

Berkman LF, Glass T, Brissette I, Seeman TE (2000) From social integration to health: Durkheim in the new millennium. Soc Sci Med 51(6):843-857

Bertrand M, Mullainathan S (2004) Are Emily and Greg more employable than Lakisha and Jamal? A field experiment on labor market discrimination. Am Econ Rev 94(4):991-1013

Borjas GJ (2006) Native internal migration and the labor market impact of immigration. J Hum Resour 41(2):221-258

Butler D, Broockman E (2011) Do politicians racially discriminate against constituents? A field experiment on state legislators. Am J Polit Sci 55(3):463-477

Carron AV, Spink KS (1993) Team building in an exercise setting. Sport Psychol 7 (1):8-18

Council of European Union (2010) Council conclusions of 18 November 2010 on the role of sport as a source of and a driver for active social inclusion. https:// eur-lex.europa.eu/legal-content/EN/TXT/PDF/?uri=CELEX:52010XG1203 (04) \&from $=$ EN. Accessed 4 Mar 2019

Cousins C (1998) Social exclusion in Europe: Paradigms of social disadvantage in Germany, Spain, Sweden and the United Kingdom. Policy Polit 26 (2):127-146 
De Haas H (2005) International migration, remittances and development: Myths and facts. Third World Q 26(8):1269-1284

Demes KA, Geeraert N (2014) Measures matter: Scales for adaptation, cultural distance, and acculturation orientation revisited. J Cross Cult Psycho 45(1):91-109

Duarte R, Araújo D, Correia V, Davids K (2012) Sports teams as superorganisms. Sports Med 42(8):633-642

Eccles DW, Tenenbaum G (2007) A social-cognitive perspective on team functioning in sport. In:Tenenbaum G, Eklund RC (eds) Handbook of Sport Psychology (Vol 3). Wiley, New York, p 264-286

Edelman B, Luca M, Svirsky D (2017) Racial discrimination in the sharing economy: Evidence from a field experiment. Am Econ J-Appl Econ 9(2):1-22

Erk J (2007) Explaining federalism: state, society and congruence in Austria, Belgium, Canada, Germany and Switzerland. Routledge, New York

Gaddis SM (2017) How black are Lakisha and Jamal? Racial perceptions from names used in correspondence audit studies. Socio Sci 4:469-89

Ge Y, Knittel CR, MacKenzie D, Zoepf S (2016) Racial and gender discrimination in transportation network companies. National Bureau of Economic Research Working Paper No. w22776

Gerber A, Green DP (2008) Field experiments and natural experiments. In: BoxSteffensmeier JM, Brady HE, Collier D (eds) The Oxford Handbook of Political Methodology. Oxford University Press, New York, p 357-381

Glaeser EL, Laibson DI, Scheinkman JA, Soutter CL (2000) Measuring trust. Q J Econ 115(3):811-846

Granovetter MS (1973) The strength of weak ties. Am J Socio 78(6):1360-1380

Hainmueller J, Hangartner D, Pietrantuono G (2017) Catalyst or crown: Does naturalization promote the long-term social integration of immigrants? Am Polit Sci Rev 111(2):256-276

Helbling M, Hoeglinger D, Wüest B (2010) How political parties frame European integration. Eur J Polit Res 49(4):495-521

Hofmann W, Gawronski B, Gschwendner T, Le H, Schmitt M (2015) A Metaanalysis on the correlation between the implicit association test and explicit self-report measures. Pers Soc Psychol B 31(10):1369-1385

Hooghe M, Reeskens T, Stolle D, Trappers A (2009) Ethnic diversity and generalized trust in Europe: A cross-national multilevel study. Comp Political Stud 42(2):198-223

Hutchinson J (2000) Ethnicity and modern nations. Ethn Racial Stud 23 (4):651-669

Katz D, Kahn RL (1978) The social psychology of organizations (Vol. 2). Wiley, New York

Kroft K, Lange F, Notowidigdo MJ (2013) Duration dependence and labor market conditions: Evidence from a field experiment. Q J Econ 128(3):1123-1167

Laurentsyeva N, Venturini A (2017) The social integration of immigrants and the role of policy-A literature review. Inter Econ 52(5):285-292

Lowe (2018) Types of contact: A field experiment on collaborative and adversarial caste integration. Unpublished manuscript

Massey DS (1988) Economic development and international migration in comparative perspective. Popul Dev Rev 14(3):383-413

Mattern KD, Shaw EJ (2010) A look beyond cognitive predictors of academic success: Understanding the relationship between academic self-beliefs and outcomes. J Coll Stud Dev 51(6):665-678

May S (2013) Language and minority rights: Ethnicity, nationalism and the politics of language. Routledge, New York

McLaren LM (2003) Anti-immigrant prejudice in Europe: Contact, threat perception, and preferences for the exclusion of migrants. Soc Forces 81(3):909-936

Musterd S (2005) Social and ethnic segregation in Europe: Levels, causes, and effects. J Urban Aff 27(3):331-348

Musterd S, Ostendorf W (2013) Urban segregation and the welfare state: Inequality and exclusion in western cities. Routledge, London

Neiman J (2017) The impact of education on legislative responsiveness in three field experiments. Cogent Soc Sci 3:1-12

Nowotny E, Mooslechner P, Ritzberger-Grünwald D (2009) The integration of European labour markets. Edward Elgar Publishing, Cheltenham

Pager D, Bonikowski B, Western B (2009) Discrimination in a low-wage labor market: A field experiment. Am Socio Rev 74(5):777-799

Pettigrew TF, Tropp LR (2006) A meta-analytic test of intergroup contact theory. J Pers Soc Psychol 90(5):751-783

Plant E, Devine P (2003) The antecedents and implications of interracial anxiety. Psychol Bull 29(6):790-801

Portes A (1997) Immigration theory for a new century: Some problems and opportunities. Int Migr Rev 31(4):799-825

Putnam RD (2001) Bowling alone: The collapse and revival of American community. Simon and Schuster, New York

Putnam RD (2007) E pluribus unum: Diversity and community in the twenty-first century. Scand Polit Stud 30(2):137-174
Richeson J, Trawalter S (2005) Why do interracial interactions impair executive function? A resource depletion account. J Pers Soc Psychol 88(6):934-947

Rumbaut RG (1997) Assimilation and its discontents: Between rhetoric and reality. Int Migr Rev 31(4):923-960

Schneider SL (2008) Anti-immigrant attitudes in Europe: Outgroup size and perceived ethnic threat. Eur Socio Rev 24(1):53-67

Schweizerische Eidgenossenschaft (2019a) Sport and leisure-facts and figures https://www.eda.admin.ch/aboutswitzerland/en/home/gesellschaft/sportund-freizeit/sport-und-freizeit---fakten-und-zahlen.html. Accessed 8 Dec 2018

Schweizerische Eidgenossenschaft (2019b) Bundesamt für Statistik-Sprachen. https://www.bfs.admin.ch/bfs/de/home/statistiken/bevoelkerung/sprachenreligionen/sprachen.html. Accessed 19 Jan 2019

Semyonov M, Raijman R, Gorodzeisky A (2006) The rise of anti-foreigner sentiment in European societies, 1988-2000. Am Socio Rev 71(3):426-449

Semyonov M, Raijman R, Yom-Tov A, Schmidt P (2004) Population size, perceive threat, and exclusion: A multiple-indicators analysis of attitudes toward foreigners in Germany. Soc Sci Res 33(4):681-701

Smith KG, Smith KA, Olian JD, Sims HP, Jr, O'Bannon DP, Scully JA(1994) Top management team demography and process: The role of social integration and communication Admin Sci Quart 39(3):412-438

Snauwaert B, Soenens B, Vanbeselaere N, Boen F (2003) When integration does not necessarily imply integration: Different conceptualizations of acculturation orientations lead to different classifications. J Cross Cult Psycho 34 (2):231-239

Van Oudenhoven JP, Eisses A (1998) Integration and assimilation of Moroccan immigrants in Israel and the Netherlands. Int J Intercult Rel 22(3):293-307

Walseth K (2008) Bridging and bonding social capital in sport-Experiences of young women with an immigrant background. Sport Educ Soc 13(1):1-7

\section{Acknowledgements}

This work was financially supported by the Forschungskredit of the University of Zurich, grant no. FK-17-019.

\section{Author contributions}

All authors contributed equally to this study and share the responsibility for its content C.N. and C.G.-G. dedicated a substantial amount of time to this project while affiliated to the University of Zurich and the University of Castilla-La Mancha, respectively.

\section{Competing interests}

The authors declare no competing interests.

\section{Additional information}

Supplementary information is available for this paper at https://doi.org/10.1057/s41599 019-0372-0.

Correspondence and requests for materials should be addressed to C.N

Reprints and permission information is available at http://www.nature.com/reprints

Publisher's note Springer Nature remains neutral with regard to jurisdictional claims in published maps and institutional affiliations.

Open Access This article is licensed under a Creative Commons Attribution 4.0 International License, which permits use, sharing, adaptation, distribution and reproduction in any medium or format, as long as you give appropriate credit to the original author(s) and the source, provide a link to the Creative Commons license, and indicate if changes were made. The images or other third party material in this article are included in the article's Creative Commons license, unless indicated otherwise in a credit line to the material. If material is not included in the article's Creative Commons license and your intended use is not permitted by statutory regulation or exceeds the permitted use, you will need to obtain permission directly from the copyright holder. To view a copy of this license, visit http://creativecommons.org/ licenses/by/4.0/

(C) The Author(s) 2019 